\title{
Customers Satisfaction on Online Shopping in Malaysia
}

\author{
Hasina Momtaz \\ Centre for Communications Skills and Entrepreneurship \\ University Malaysia Perlis (UniMAP), Perlis 01000, Malaysia \\ E-mail: hasina@unimap.edu.my
}

Md. Aminul Islam

School of Business Innovation and Technopreneurship

Universiti Malaysia Perlis, Perlis 01000, Malaysia

E-mail: amin@unimap.edu.my

$\mathrm{Ku}$ Halim Ku Ariffin

School of Business Innovation and Technopreneurship

Universiti Malaysia Perlis, Perlis 01000, Malaysia

E-mail: ku.halim@unimap.edu.my

Anayet Karim

School of Electrical Systems Engineering

Universiti Malaysia Perlis, Perlis 01000, Malaysia

E-mail: anayet@unimap.edu.my

Received: February 21, $2011 \quad$ Accepted: March 28, $2011 \quad$ Published: October 1, 2011
doi:10.5539/ijbm.v6n10p162

\begin{abstract}
This research attempted to find out the factors that are affecting customers' intention and satisfaction to shop online. To shop on Internet becomes an alternative for consumers since it is more comfortable than conventional shopping which usually attributed with anxious, crowded, traffic jam, limited time, parking space and etc. Internet in Malaysia is still considered as a new medium toll between the retailers and the consumers, and also retaining customers on e-retail is the most issue that is faced any e-retail store. To increase the understanding in this area, the following questions need correct answers. Are Malaysians ready to embrace Internet shopping? In addition, this study intends to know the reasons, why Malaysian customers accept or refuse internet shopping application? And what are dominant predictors that influence the customers' intention to shop on internet in Perlis, Malaysia? This research adopted survey by questionnaire approach. Questionnaires will be distributed among general public including student at the university to gauge their intention to shop online. Findings of this research will provide a yardstick to customer satisfaction and online shopping based on various issues such as advertisement, brand, shopping experience, time, trust etc.
\end{abstract}

Keywords: Customer satisfaction, Online shopping, Perceived usefulness, Perceived ease of use, Malaysia

\section{Introduction}

A fundamental understanding of factors impacting online customer satisfaction is of great importance to e-commerce. Customer satisfaction is the consequence of experiences during various purchasing stages: needing something, gathering information about it, evaluating purchasing alternatives, actual purchasing decision, and post purchasing behavior (Kotler \& Keller, 2006). Do advertisements, product quality, brand, shopping experiences relate to customer satisfaction on online shopping? Shopping for products on the internet has 
become an alternative for consumer since it is more comfortable than conventional shopping which usually attributed with anxious, crowded, traffic jam, limited time, parking space and, etc (Norazah Mohd Suki, T. Ramayah \& Norbayah Mohd Suki, 2008).

The internet offers benefits which help consumers to become more efficient and effective towards online shopping. Consumer's efficiency can be enhanced by online shopping to provide rapid access to product related information, saving consumers time, effort and money, quality of the product, and shopping experience (McGaughey \& Mason, 1998). Products that are being marketed through the internet can be classified into two groups. The first group of products contains items that consumer do not need to see in person before purchasing. These products which include everything from computers, compact discs to scanned goods can be evaluated using just text, pictures and other digitally communicable information. This group of products is ideally suited to internet shopping whereby the internet could serve significant transaction and communication functions. The second group of products is termed as experience products, which items that consumers prefer to see and touch purchasing, such as clothes and groceries. This group of product is not suitable for internet shopping since information about the products features may not be sufficient for consumers to engage in internet based transactions (Ahasanul Haque \& Ali Khatibi, 2007).

The aim of this study is to know the determinants of issues how to shop through online. The objective of this study is to empirically examine the relationship between online shopping factors and customer satisfaction. The specific objectives of the study are 1) to identify the factors affected online customer satisfaction and 2) to examine the relationship between online customer satisfaction and its related IV such as advertisements, product quality, brand, shopping experiences etc.

\section{Literature Review}

Today most consumers are looking for ways to streamline their shopping. Therefore, consumers tend to want to get items quickly without bargaining on price or quality, hence, e-shopping has become an important consideration. Consumers can order an amazing variety of products via the internet (Yomnak, 2007). Customers like online shopping, because online shopping saves time. Online shopping is indoor shopping, no need to go outside. By rapid access customers get information quickly. Online shopping eliminates of physical appearance. On over all, online shopping is the easiest way to purchase products.

Online shopping in the western countries is very common to all but for Malaysia it is very challenging. In Malaysia, online shopping is something new, therefore the transactions are very limited. The Malaysian people still believe that online transactions are not secured enough to protect the payment method such as credit card and also disclosure of information (Ahasanul Haque \& Ali Khatibi, 2007).

In online shopping, sometimes consumers are not satisfied with the manner in which products and services are sold in the online environment. Sometimes items purchased from online do not deliver on time even though online message is very clear to deliver the item within 24 hours to the customer. The strategies that marketers are using have not adequately addressed the changing demands of the consumer to ensure customer satisfaction (Day $\&$ Landon, 1977). The marketing function limits the scope of marketing strategies in operating successfully online. New electronic communication marketing variables have exploded the alternatives available to customers globally. These changes have redefined many of the old views of marketing, trade and power. Furthermore, many researchers recognize and accept that customer satisfaction is a logical measurement of success in market exchanges (Dubrovski, 2001).

\section{Advertisements}

The advertisements are in the form of a slam rectangular graphic image that is linked to a target advertisement which generally appears at the top or the bottom of web site and contain a short text or graphical message that can be customized for target audiences. According to Kierzkowski, McQade, Waltman, \& Zeisser, (1996), this can be achieved by billboard advertisement, links from other sited and leveraging on existing marketing communication, termed piggy-back advertising. Companies need to develop website with customer service in mind (Karakaya 2001).

\section{Product Quality}

Customers are satisfied when the perceived service meets or exceeds their expectation. They are dissatisfied when they feel the service falls below their expectations. Quality and customer satisfaction has provided some insights into determining the levels of satisfaction for product experience. Customer service and a positive customer experience are critical to sales in the e-commerce market place. Product quality is customers' overall evaluation of the excellence of the performance of the good or service (John, Mowen \& Michael 1997). When a 
customer recognizes quality, it is reflected in customer satisfaction. Delivering quality to customers in a competitive marketplace dictates the need to continually enhance a customer's experience and satisfaction.

\section{Brand}

Brand management in the twenty-first century has become almost synonymous with building and managing customer relationships (John Story \& Jeff Hess, 2010). Branding today is the formal introduction of the company, what it stands for, and the product it provides the consumer. A brand is a promise or a set of guidelines in the minds of the customer about what the company will do it. Brand building takes consistency, and commitment, to ensure that the brands communicate the desired message to the consumer. Branding is a relationship that is built on understanding and satisfaction (Higgins, 1999).

\section{Shopping Experience}

A shopping experience is the cognitions and feelings the consumer experiences during the use of a product or services (John et al. 1997). The process of consumer behavior describes the basic steps that an ultimate consumer goes through in satisfying what customer wants in the market a) problem recognition, b) information search c) choice and post decision evaluation (Pine \& Gilmore, 1990). The customer experience may provide a new means of competition (J. Robert \& K. Xiangyu, 2011).

Figure 1 show the online customer satisfaction research model in this project. There is significant correlation among advertisement, product quality, brand and shopping experiences with customer satisfaction. Familiarity to the above variables is a very important factor to increase customer satisfaction.

Four hypotheses has been developed for this study which are given below-

$\mathbf{H}_{1}$ : Advertisement positively related to the Customer satisfaction when they shop online.

$\mathbf{H}_{2}$ : Product Quality positively related to Customer satisfaction in online shopping.

$\mathbf{H}_{3}$ : Brands play an important role to the Customer satisfaction in online shopping.

$\mathbf{H}_{4}$ : Online Shopping experience and Customer satisfaction are positively related.

\section{Research Methodology}

This was a correlation study (Sekaran, 2000) which attempted to investigate the statistical relationship between the online customer satisfaction with few independent variables such as advertisements, product quality, brand and shopping experience. The sample for this study consisted of general public including university students in University Malaysia Perlis and University Utara Malaysia. The non-probability convenience sampling (Sekaran, 2000) was chosen as the sampling design in this study. This was because convenience sampling is most often used during the exploratory phase of a research project and in perhaps the best way of getting some basic information quickly and efficiently. A total of 130 questionnaires were distributed at general public and the university students, of the130, one hundred (100) samples have been collected.

In this study, a five page questionnaire which consisted of 28 close ended questions was employed. There are two sections in the questionnaire- section A \& section B. Section A indicating demographic information and section B indicating variables related information which measured online customer satisfaction which comprise five variables. The resulting questionnaire consisted of twenty eight (28) closed questions including demographics questions. Twenty three of the questions consisted of a range of responses of strongly agree to disagree, on a 5 point scale. These questions incorporated all of the variables that were determined to be an important in the customer satisfaction.

\section{Results}

Table 1 depicts the demographic profile of respondents. In this study demographic variables consisted of gender, age, education level, monthly income \& marital status.

\subsection{Reliability Analysis}

The Cronbach alpha values of the study variables are shown in Table 2. As revealed in Table 2, the reliability coefficient of the study variables exceeded the minimum acceptable level of 0.70 (Nunnally \& Bernstein, 1994)

\subsection{Descriptive Statistics}

The online customer satisfaction, advertisement, brand and shopping experience were measured based on a 5 point Likert scale. Table 3 highlights the results of the descriptive analysis in terms of means and standard deviations for variables. 


\subsection{Correlation Analysis}

To examine the bivariate relationships among the variables, a Pearson's correlation analysis was carried out. Results shows that variables are correlated but none of the $\mathrm{p}$-values are more than 0.70 . This indicates that there is no multicolleniarity problem among variables.

\subsection{Regression Analysis}

Regression analysis is used to test the hypothesized relationships among the variables. The result of each hypothesis is summarized here. All result shown above measured with $\alpha=0.05$.

\subsubsection{Customer Satisfaction and Advertisements}

The first regression analysis was carried out to determine the relationship between advertisement and consumer satisfaction when they shop online. The regression output is presented in Table 4 and 5. The output shows the Durbin Watson value close to 2 (1.330), which indicates that there was no auto-correlation problem of error terms. From the coefficient matrix of this model, customer satisfaction based on the information about that received by particular customer in online is significant at $\mathrm{t}=4.66$ and $P=0.005<0.05$ which support $\boldsymbol{H}_{1 \text {. }}$. The $\mathrm{P}$ value indicating that online shopping has relationship between the advertisement and the customer satisfaction which shown in Table 4 and 5 .

\subsubsection{Customer Satisfaction and Product Quality}

The second regression analysis was carried out to determine the relationship between product quality and consumer satisfaction. The regression output is presented in Table 6 and7. The output for product quality is major criteria to shop online and satisfaction of shopping needs shows the Durbin Watson value is 1.646. The result of Durbin Watson also indicates that there is positive serial correlation. According to the rule of Durbin-Watson, if the Durbin-Watson statistic is substantially less than 2, there is evidence of positive serial correlation. From the coefficient matrix of this model, product quality is major criteria to shop online is significant at $\boldsymbol{t}=6.103$ and $P=0.00<0.05$.

The product quality support $\boldsymbol{H}_{2}$. This means the product quality has a relationship with customer satisfaction which indicating from Table $6 \& 7$.

\subsubsection{Customer Satisfaction and Brands}

The third regression analysis was carried out to determine the relationship between role of brand to purchase online and consumer satisfaction. The regression output is presented in Table 8 and 9 . The output for brands play an important role to purchase product online and satisfaction of shopping needs purchasing online shows the Durbin Watson value is 1.286 , which indicates that there was no auto-correlation problem of error terms.

The result of Durbin Watson also indicates that there is positive serial correlation. According to the rule of Durbin-Watson, if the Durbin-Watson statistic is substantially less than 2, there is evidence of positive serial correlation. From the coefficient matrix of this model, brands play an important role to purchase product online is significant at $\boldsymbol{t}=5.309$ and $P=0.00<0.05$.

This result supports the $\boldsymbol{H}_{3}$. It means brands play an important role when customer purchases online to satisfy them.

\subsubsection{Customer Satisfaction and Shopping Experiences}

The last regression analysis was carried out to determine the relationship between online shopping experience and consumer satisfaction when they shop online. The regression output is presented in Table 10 and 11. The output satisfaction of shopping experience in online and satisfaction of shopping needs purchasing online shows the Durbin Watson value is 1.589 , which indicates that there was no auto-correlation problem of error terms.

The result of Durbin Watson also indicates that there is positive serial correlation. According to the rule of Durbin-Watson, if the Durbin-Watson statistic is substantially less than 2, there is evidence of positive serial correlation. From the coefficient matrix of this model, satisfaction of shopping experience in online is significant at $\boldsymbol{t}=9.557$ and $P=0.00<0.05$.

This result supports the $\boldsymbol{H}_{\boldsymbol{4}}$. It means satisfaction of shopping experience in online and the customer satisfaction is positively related.

\section{Conclusion}

Online customer satisfaction is the fundamental to the marketing concept. This study was conducted with the purpose of measuring customer satisfaction. Specially, the first objective of this study was to identify the factors 
affected online customer satisfaction. The second objective was to examine the relationship between online customer satisfaction and advertisements, product quality, brand and shopping experiences. Prior researches on online shopping documented that advertisements, product quality, brand and shopping experiences are related to customer satisfaction on online shopping. This study then attempted to find out whether these factors also play significant role in satisfying online shoppers in Malaysia. Findings confirmed that advertisements, product quality, brand names, and prior shopping experiences do play a significant role in customer satisfaction among online shoppers in Malaysia. It is hoped that these results could provide some insight for researchers and practitioners to understand more about customer satisfaction on online shopping. This study provides many opportunities for future research, for example Vijayasarathy (2003) suggested a wide range of possible salient beliefs about shopping on-line. Future research should address other relevant constructs that affects customer satisfaction on online shopping. The measures created for this study should support future research. It is clear that more and different variables are needed to understand shopping on Internet fully. It is relatively new phenomenon, and as such may require additional rethinking of used models.

\section{Acknowledgement}

The author would like to thank to the Center for Communications Skills and Entrepreneurship, University Malaysia Perlis (UniMAP) for the field survey and financial support.

\section{References}

Ahasanul Haque \& Ali Khatibi. (2007). The Impact of internet marketing on customer satisfaction: A study Malaysian perspective. Journal of Mobile communication, 1 (1) 29-35.

Day, R., \& E. Landon. (1977). Toward a theory of consumer complaining behavior. Consumer and Industrial Buying Behavior.

Dubrovski, D. (2001). The role of consumer satisfaction in achieving business excellence. Total Quality Management.

Higgins. (1999). The value of customer value analysis: customer value analysis becomes the starting point in marketing research. Marketing Research.

John C. Mowen., \& Michael S. Minor. (1997). Consumer behavior: A Framework: 1997.

John Story \& Jeff Hess. (2010). Ethical brand management: customer relationships and ethical duties. Journal of Product \& Brand Management, 19/4. http://dx.doi.org/10.1108/10610421011059568

Karakaya, F. (2001). Electronic commerce current and future practices. Managerial finance.

Kierzkowski, A., S. McQade, R. Waltman, \& M. Zeisser. (1996). Marketing to the digital customer. The mckinsey quarterly.

McGaughey R, \& K. Mason, (1998). The internet as a marketing tool. Journal of Marketing Theory and Practices.

Norazah Mohd Suki, T. Ramayah \& Norbayah Mohd Suki. (2008). Internet shopping acceptance Examining the influence of intrinsic versus extrinsic motivations. Direct Marketing: An International Journal pp. 97-110

Robert Johnston \& Xiangyu Kong. (2011). The customer experience: a road-map for improvement. Managing Service Quality, pp. 5-24. http://dx.doi.org/10.1108/09604521111100225

Sekaran, U. (2000). Research methods for business: A skill-building approach ( ${ }^{\text {rd }}$ Ed.).

Tortrakul Yomnak. (2007). Perceptions of service quality and customer satisfaction of on-line shopping services.

Vijayasarathy L.R. (2003). Predicting consumer intentions to use on-line shopping: the case for an augmented technology acceptance model. Information and Management (August). 
Table 1. Summary of Demographic Profile

\begin{tabular}{|l|l|l|l|}
\hline Demographic Variables & Categories & Frequency & Percentage (\%) \\
\hline Gender & Male & 59 & 59 \\
& Female & 41 & 41 \\
\hline Age & Less than 20 years old & 11 & 11 \\
& 21 to 30 years old & 85 & 85 \\
& 31 to 40 years old & 4 & 4 \\
& 41 to 50 years old & 0 & 0 \\
& 51 to 60 years old & 0 & 0 \\
\hline Education Level & Certificate & 0 & 0 \\
& Diploma & 0 & 0 \\
& Degree & 90 & 90 \\
& Master & 10 & 10 \\
& PhD & 0 & 0 \\
\hline Marital Status & Single & 86 & 86 \\
& Married & 12 & 12 \\
& Widow & 0 & 0 \\
& Divorce & 2 & 2 \\
\hline Monthly Income & Less than RM 1,000 & 87 & 87 \\
& RM 1,000 to RM 1,499 & 6 & 6 \\
& RM 1,500 to RM 2,499 & 3 & 3 \\
& RM 2,500 to RM 4,000 & 4 & 4 \\
\hline
\end{tabular}

Table 2. Summary of Reliability Test

\begin{tabular}{|l|c|c|c|}
\hline Variables & Number of items & Number of item included & Cronbach Alpha \\
\hline Advertisement & 6 & 6 & 0.691 \\
\hline Product Quality & 5 & 5 & 0.551 \\
\hline Brand & 3 & 3 & 0.733 \\
\hline Shopping Experience & 9 & 9 & 0.836 \\
\hline
\end{tabular}

Table 3. Descriptive Statistics

\begin{tabular}{|c|c|c|c|c|c|}
\hline & $\mathrm{N}$ & Minimum & Maximum & Mean & Std. Deviation \\
\hline A1 & 100 & 1.00 & 5.00 & 2.5100 & 1.14146 \\
A2 & 100 & 1.00 & 5.00 & 2.8600 & 1.06382 \\
A3 & 100 & 1.00 & 5.00 & 2.5500 & 1.04809 \\
A4 & 100 & 1.00 & 5.00 & 2.4600 & 1.05811 \\
A5 & 100 & 1.00 & 5.00 & 2.4300 & 1.13933 \\
PQ1 & 100 & 1.00 & 5.00 & 2.8700 & 1.14287 \\
PQ2 & 100 & 1.00 & 5.00 & 2.6100 & .88643 \\
PQ3 & 100 & 1.00 & 5.00 & 2.8200 & 1.03845 \\
PQ4 & 100 & 1.00 & 5.00 & 2.4000 & 1.08246 \\
SE1 & 100 & 1.00 & 5.00 & 2.8100 & .97125 \\
SE2 & 100 & 1.00 & 5.00 & 2.6600 & .97670 \\
SE3 & 100 & 1.00 & 5.00 & 2.8500 & .89188 \\
SE4 & 100 & 1.00 & 5.00 & 2.8600 & 1.00524 \\
SE5 & 100 & 1.00 & 5.00 & 2.8600 & 1.01524 \\
SE6 & 100 & 1.00 & 5.00 & 2.9700 & .97913 \\
SE7 & 100 & 1.00 & 5.00 & 3.1700 & 1.15518 \\
BI1 & 100 & 1.00 & 5.00 & 2.1500 & .99874 \\
BI2 & 100 & 1.00 & 5.00 & 2.4300 & 1.05653 \\
Valid N (listwise) & 100 & & & & \\
\hline
\end{tabular}


Table 4. Model Summary

\begin{tabular}{|c|c|c|c|c|c|c|c|c|c|c|}
\hline \multicolumn{11}{|c|}{ Model Summary $^{\mathrm{b}}$} \\
\hline \multirow[t]{2}{*}{ Model } & \multirow[t]{2}{*}{$\mathrm{R}$} & \multirow{2}{*}{$\begin{array}{l}\mathrm{R} \\
\text { Square }\end{array}$} & \multirow{2}{*}{$\begin{array}{l}\text { Adjusted } \\
\mathrm{R} \\
\text { Square }\end{array}$} & \multirow{2}{*}{$\begin{array}{l}\text { Std. } \\
\text { Error of } \\
\text { the } \\
\text { Estimate }\end{array}$} & \multicolumn{5}{|c|}{ Change Statistics } & \\
\hline & & & & & $\begin{array}{l}\text { R } \\
\text { Square } \\
\text { Change }\end{array}$ & $\begin{array}{l}\mathrm{F} \\
\text { Change }\end{array}$ & $\mathrm{df1}$ & $\mathrm{df} 2$ & $\begin{array}{l}\text { Sig. F } \\
\text { Change }\end{array}$ & $\begin{array}{l}\text { Durbin- } \\
\text { Watson }\end{array}$ \\
\hline 1 &, $426^{\mathrm{a}}$ &, 181 & , 173 &, 8823 &, 181 & 21,716 & 1 & 98 &, 000 & 1,330 \\
\hline
\end{tabular}

a. Predictors: (Constant), Adv_mean

b. Dependent Variable: SE1

Table 5. Coefficients

\begin{tabular}{|l|l|l|l|l|l|}
\hline \multicolumn{7}{|c|}{ Coefficients $^{\mathrm{a}}$} & \multirow{2}{*}{ Sig. } \\
\cline { 1 - 4 } Model & \multicolumn{2}{|c|}{$\begin{array}{c}\text { Unstandardized } \\
\text { Coefficients }\end{array}$} & $\begin{array}{l}\text { Standardized } \\
\text { Coefficients }\end{array}$ & $\mathrm{t}$ & \\
\hline & $\mathrm{B}$ & Std. Error & Beta & 4,190 &, 000 \\
\hline 1 (Constant) & 1,357 &, 324 & & 4,660 &, 000 \\
\hline Adv_mean &, 567 &, 122 &, 426 & \\
\hline
\end{tabular}

a. Dependent Variable: SE1

Table 6. Model Summary

\begin{tabular}{|c|c|c|c|c|c|c|c|c|c|c|}
\hline \multicolumn{11}{|c|}{ Model Summary $^{\mathrm{b}}$} \\
\hline \multirow[t]{2}{*}{ Model } & \multirow[t]{2}{*}{$\mathrm{R}$} & \multirow{2}{*}{$\begin{array}{l}\mathrm{R} \\
\text { Square }\end{array}$} & \multirow{2}{*}{$\begin{array}{l}\text { Adjusted } \\
\mathrm{R} \\
\text { Square }\end{array}$} & \multirow{2}{*}{$\begin{array}{l}\text { Std. } \\
\text { Error of } \\
\text { the } \\
\text { Estimate }\end{array}$} & \multicolumn{5}{|c|}{ Change Statistics } & \\
\hline & & & & & $\begin{array}{l}\mathrm{R} \\
\text { Square } \\
\text { Change }\end{array}$ & $\begin{array}{l}\mathrm{F} \\
\text { Change }\end{array}$ & $\mathrm{df1}$ & df2 & $\begin{array}{l}\text { Sig. F } \\
\text { Change }\end{array}$ & $\begin{array}{l}\text { Durbin- } \\
\text { Watson }\end{array}$ \\
\hline 1 &, $525^{\mathrm{a}}$ & ,275 & ,268 &, 83098 & 275 & 37,244 & 1 & 98 &, 000 & 1,646 \\
\hline
\end{tabular}

a. Predictors: (Constant), pq_mean

b. Dependent Variable: SE1

Table 7. Coefficients

\begin{tabular}{|c|c|c|c|c|c|c|}
\hline \multicolumn{7}{|c|}{ Coefficients $^{\mathrm{a}}$} \\
\hline \multirow{2}{*}{\multicolumn{2}{|c|}{ Model }} & \multicolumn{2}{|c|}{ Unstandardized Coefficients } & Standardized & \multirow[t]{2}{*}{$\mathrm{t}$} & \multirow[t]{2}{*}{ Sig. } \\
\hline & & $\mathrm{B}$ & Std. Error & Beta & & \\
\hline 1 & (Constant) & ,806 & ,339 & & 2,379 &, 019 \\
\hline & $\mathrm{pq}$ mean & ,749 &, 123 &, 525 & 6,103 &, 000 \\
\hline
\end{tabular}

a. Dependent Variable: SE1

Table 8. Model Summary

\begin{tabular}{|c|c|c|c|c|c|c|c|c|c|c|}
\hline \multicolumn{11}{|c|}{ Model Summary ${ }^{\mathrm{b}}$} \\
\hline \multirow[t]{2}{*}{ Model } & \multirow[t]{2}{*}{$\mathrm{R}$} & \multirow{2}{*}{$\begin{array}{l}\mathrm{R} \\
\text { Square }\end{array}$} & \multirow{2}{*}{$\begin{array}{l}\text { Adjusted } \\
\mathrm{R} \\
\text { Square }\end{array}$} & \multirow{2}{*}{$\begin{array}{l}\text { Std. } \\
\text { Error of } \\
\text { the } \\
\text { Estimate }\end{array}$} & \multicolumn{5}{|c|}{ Change Statistics } & \multirow[b]{2}{*}{$\begin{array}{l}\text { Durbin- } \\
\text { Watson }\end{array}$} \\
\hline & & & & & $\begin{array}{l}\mathrm{R} \\
\text { Square } \\
\text { Change }\end{array}$ & $\begin{array}{l}\text { F } \\
\text { Change }\end{array}$ & df1 & $\mathrm{df} 2$ & $\begin{array}{l}\text { Sig. F } \\
\text { Change }\end{array}$ & \\
\hline 1 &, $473^{\mathrm{a}}$ & ,223 &, 215 &, 86027 &, 223 & 28,191 & 1 & 98 &, 000 & 1,286 \\
\hline
\end{tabular}

a. Predictors: (Constant), br_mean

b. Dependent Variable: SE1

Table 9. Coefficients

\begin{tabular}{|c|c|c|c|c|c|c|}
\hline \multicolumn{7}{|c|}{ Coefficients $^{\mathrm{a}}$} \\
\hline \multirow{3}{*}{\multicolumn{2}{|c|}{ Model }} & \multirow{2}{*}{\multicolumn{2}{|c|}{$\begin{array}{c}\text { Unstandardized } \\
\text { Coefficients }\end{array}$}} & Standardized & \multirow[t]{3}{*}{$\mathrm{t}$} & \multirow[t]{3}{*}{ Sig. } \\
\hline & & & & Coefficients & & \\
\hline & & $\mathrm{B}$ & Std. Error & Beta & & \\
\hline \multirow[t]{2}{*}{1} & (Constant) & 1,659 & ,233 & & 7,114 &, 000 \\
\hline & br_mean &, 503 &, 095 &, 473 & 5,309 &, 000 \\
\hline
\end{tabular}

a. Dependent Variable: SE1 
Table 10. Model Summary

\begin{tabular}{|c|c|c|c|c|c|c|c|c|c|c|}
\hline \multicolumn{11}{|c|}{ Model Summary $^{\mathrm{b}}$} \\
\hline \multirow[t]{2}{*}{ Model } & \multirow[t]{2}{*}{$\mathrm{R}$} & \multirow{2}{*}{$\begin{array}{l}\mathrm{R} \\
\text { Square }\end{array}$} & \multirow{2}{*}{$\begin{array}{l}\text { Adjusted } \\
\mathrm{R} \\
\text { Square }\end{array}$} & \multirow{2}{*}{$\begin{array}{l}\text { Std. } \\
\text { Error of } \\
\text { the } \\
\text { Estimate }\end{array}$} & \multicolumn{5}{|c|}{ Change Statistics } & \\
\hline & & & & & $\begin{array}{l}\mathrm{R} \\
\text { Square } \\
\text { Change }\end{array}$ & $\begin{array}{l}\text { F } \\
\text { Change }\end{array}$ & $\mathrm{df1}$ & $\mathrm{df} 2$ & $\begin{array}{l}\text { Sig. F } \\
\text { Change }\end{array}$ & $\begin{array}{l}\text { Durbin- } \\
\text { Watson }\end{array}$ \\
\hline 1 &, $695^{\mathrm{a}}$ & , 482 &, 477 & ,70231 & ,482 & 91,340 & 1 & 98 &, 000 & 1,589 \\
\hline
\end{tabular}

a. Predictors: (Constant), se_mean

b. Dependent Variable: SE1

Table 11. Coefficients

\begin{tabular}{|l|l|l|l|l|l|l|}
\hline \multicolumn{7}{|c|}{ Coefficients $^{\mathrm{a}}$} \\
\hline \multirow{2}{*}{ Model } & \multicolumn{2}{|c|}{$\begin{array}{c}\text { Unstandardized } \\
\text { Coeficients }\end{array}$} & $\begin{array}{l}\text { Standardized } \\
\text { Coefficients }\end{array}$ & $\mathrm{t}$ & Sig. \\
\cline { 3 - 7 } & B & Std. Error & Beta & &, 255 &, 800 \\
\hline 1 & (Constant) &, 075 &, 295 &, 695 & 9,557 &, 000 \\
\hline & se_mean &, 949 &, 099 &, 095 & &
\end{tabular}

a. Dependent Variable: SE1

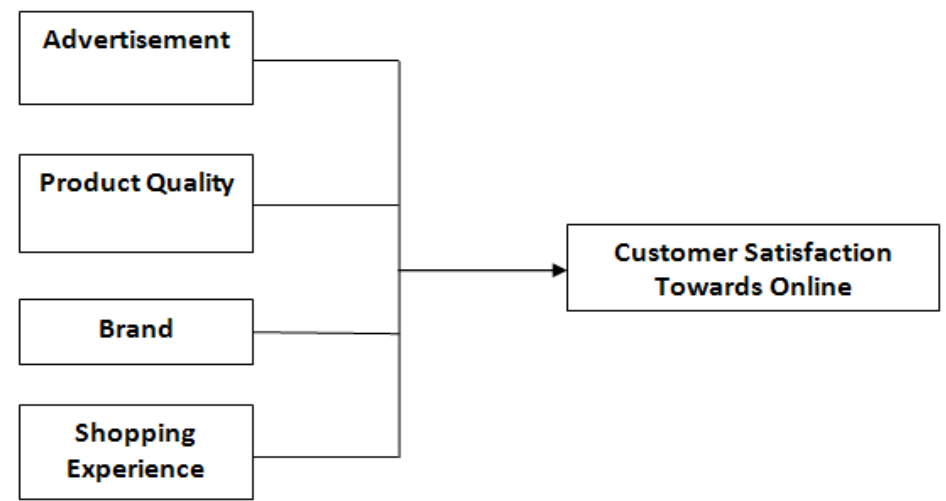

Figure 1. Research Framework 